\title{
CHARACTERISTICS OF FRUIT FROM DIFFERENT PROGENIES OF JUJUBE (ZIZYPHUS JUJUBA MILL.)
}

\author{
Aleksandar Markovski \\ Institute of Agriculture, Ss. Cyril and Methodius University, Skopje, Republic of Macedonia \\ e-mail: maraleks@yahoo.com
}

\begin{abstract}
The pomological characteristics of five varieties and one wild form of jujube progenies were examined in the experimental orchard of the Institute of Agriculture in Skopje during 2002-2004. The seeds from the varieties: Zu tao czao, Da baj czao, Kitajski 2A, Ja czao, Vahshski 45-2, and Wild midleasiatic jujube type were obtained by open pollination. Some characteristics of the fruits such as: mass of the fruits $(\mathrm{g})$, fruit density $\left(\mathrm{g} / \mathrm{cm}^{3}\right)$, mass of the seed $(\mathrm{g})$, and randman $(\%)$ were investigated in 7-9 years old jujube seedlings grown from that seed material and planted in the frames of a breeder field. A dominant mother effect in the inheritance was registered in the mass and density of the fruits. For instance: the variety Kitajski $2 \mathrm{~A}$ and the types from its progeny were characterized by the greatest mass of the fruits, while, the greatest density was found in the fruits of the variety Da bai czao and the types from its progeny. The greatest mass of the seed was recorded in the variety Kitajski 2A, while the biggest average mass of the seeds was characteristic for the progeny of the Ja czao variety.
\end{abstract}

Key words: jujube; open pollination; variety; type; fruit

\section{INTRODUCTION}

The jujube is a relatively new fruit kind which slowly but surely spreads in the fruit orchards. The characteristics, such as the late start of vegetation (late April), late blooming (the beginning of June) and long period of blooming (1-2 months), as well as the resistance to drought, make this fruit crop very interesting for growing in the present conditions of frequent climate changes. In our decades-long experiences in the breeding of this fruit kind there have been no records of falling or reducing of the yield in some critical years, unlike of some of the traditional fruit kinds as plum, apricot, almond, etc. Because of the genetic predispositions to resist to the external factors, the breeding programmes for this fruit kind are targeted in the direction of increasing of the size and quality of the fruits. There is a limited number of jujube varieties with large fruits. The fruit weight, fruit size and seed weight showed high genetic advance. The genetic advance expressed as a percentage of mean ranged from $12.48 \%$ (fruit length) to $61.16 \%$ (yield/plant) [1]. More and more work is being done to increase the randman and the time of keeping of the fresh fruits. Hence, the main goal of this work is to obtain types with improved fruit characteristics through a mass selection among the jujube varieties progenies.

\section{EXPERIMENTAL SECTION}

The investigations were performed under conditions of selection orchard with planting distance of 4 $\times 2 \mathrm{~m}$, planted in 1997 with two years old seedlings of jujube varieties. In the investigation period plants were 7-9 years old, which means that they were at the beginning of full fruitfulness The plants were grown without intervened pruning, left to develop naturally shaped crown, specific for each genotype. 131 genotypes (62\% surviving plants, because of difficulties in transplantation) of progenies, obtained by open pollination between six jujube introduced genotypes are examined. 35 seedlings of each mother variety are 
planted in. As a control 3 trees of six mothers varieties with grafted technique "whip grafting" in 1998 were used. The classification, according to the size of fruits, was performed by Sìno [2] in three groups: with large, medium and small fruits. In the group with large fruits the varieties/types with a mass of fruit greater than $12 \mathrm{~g}$ were included. The group with medium fruit size included varieties/types with a mass of fruit from 7 to $10 \mathrm{~g}$. The varieties/types with a mass of fruit below $7 \mathrm{~g}$ belonged to the group with small fruit varieties.

The mass of fruits and stones, fruit density, and randman were analyzed. The examined properties varied and were statistically processed according to Mudra [3] in two levels of probability (0.05 and 0.01).

\section{RESULTS AND DISCUSSION}

The mass of the fruits unified the total quantitative characteristics of the jujube varieties and types [4]. The fruit weight per fruit had low heritability along with low genetic advance, indicating that dominance of epistatic effect was considerable on these characters, and hence a little improvement was possible through selection [1]. Yield of zizyphus genotypes had a significantly positive correlation with the spread, fruit weight and stone size. The fruit size had a highly positive correlation with the fruit weight and stone size. Fruit weight, fruit size and stone size were the main parameters for a yield which contributed via fruit weight [5]. From the variety $\mathrm{Zu}$ tao czao progeny analysis it was determined that the type 37/1 had the biggest mass of the fruits $(13.4 \mathrm{~g})$, which is twice bigger than the average mass of the $\mathrm{Zu}$ tao czao progeny fruits (7.6 g) or for about one-third bigger $(9.5 \mathrm{~g})$ than the fruit mass of the mother variety (Table 1). Actually, $25 \%$ of the progeny types had bigger mass of the fruits than the variety $\mathrm{Zu}$ tao czao. The high heritability of these characteristics, coupled with genetic advance for yield $(\mathrm{kg} / \mathrm{plant})$, pulp/stone ratio, indicated that it was probably due to an additive gene effect [6]. Heritability was high for fruit weight $(97.2 \%)$ and size $(87.9 \%)$, pulp/stone ratio $(87.5 \%)$ and seed weight $(84.6 \%)$ in jujube at Hisar [1]. There were significant positive correlations between fruit yield, fruit set, and pulp/stone ratio of jujube (cv. Umran), whereas the yield had significant negative correlations with fruit drop and stone weight [1].

There were recorded large differences in fruit density between the types from the $\mathrm{Zu}$ tao czao variety. The type $22 / 1$ had the smallest stone from the types in the progeny. Actually, $80 \%$ from the types had the smallest stone, and about $40 \%$ greater randman than the mother variety.

The statistical analysis showed no significant differences between the mother variety and an average of the types. The type 37/1 deviated significantly with regard to all parameters.

With the comparative analysis of the characteristic data (Figure 1) it was determined that minor negative dependence between mass of the fruit and fruit density existed, as well as a slight positive dependence between the mass of the fruit and the mass of the stone (seed).

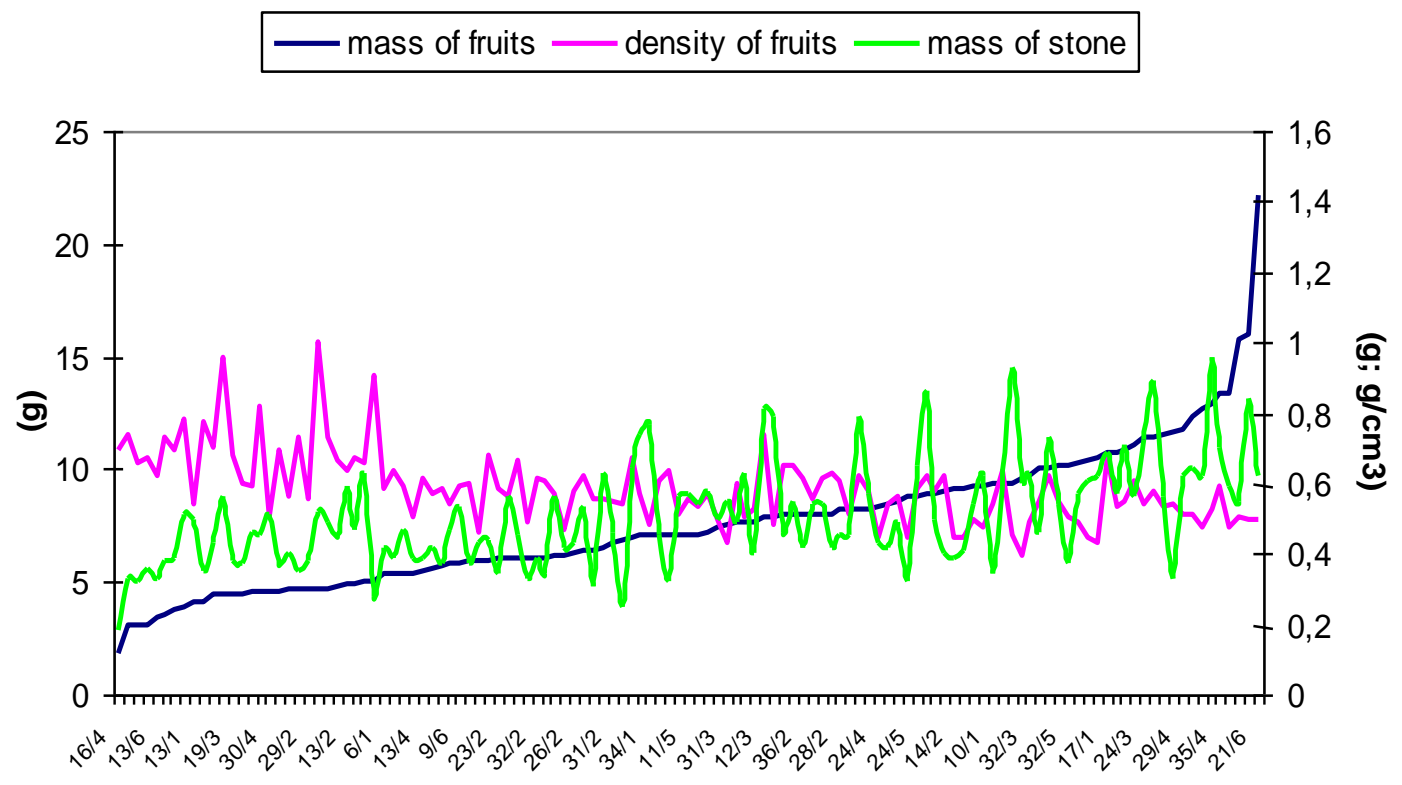

Figure 1. Dependence between fruit characteristics of all progeny types. The primary y-axis is for values of the mass of fruits, and the secondary $y$-axis is for the mass of stone and density of fruit. 
From this figure it can be seen that types with small fruits had stronger variation in the fruit density, while the types with larger fruits had greater variation in the stone (seed) mass. Generally, the types with smaller fruits had higher density of fruit, with rare exceptions. The data analysis showed no statistical difference between the variety and the average of types in relation to stone mass (Table 1). $42-50 \%$ of the types showed a significant difference and $17-20 \%$ of the types had very significantly less mass of the stone than the mother variety.

In the variety Da baj czao the largest density of the fruits had the mother variety Da baj czao (Table 1). The highest mass of the fruits had the type $3 / 2$. This type statistically deviated very significantly from the mother variety in terms of the mass of fruits and from the $24 \%$ of the types in progeny.
The type $6 / 2$ had the lowest stone mass (Table 1). The highest randman had the same type $6 / 2$. $40 \%$ of the types had a higher randman than the mother variety. There were no statistically significant differences between the mother variety and an average of the types, and individually among the types in progeny in terms of stone mass. The progeny of the mother variety Da baj czao had on average the smallest mass $(6.3 \mathrm{~g})$, but also the biggest density of the fruits $\left(0.600 \mathrm{~g} / \mathrm{cm}^{3}\right)$, compared with the other progenies. Because of the small fruits, the progeny of the mother variety Da baj czao, besides the smallest mass of the seed $(0.43 \mathrm{~g})$, had almost the lowest percent of the fruit randman, excluding the Ja czao progeny (Table 1)

Table 1. Fruit characteristics of the varieties $\mathrm{Zu}$ tao czao, Da baj czao, Ja czao and their progenies

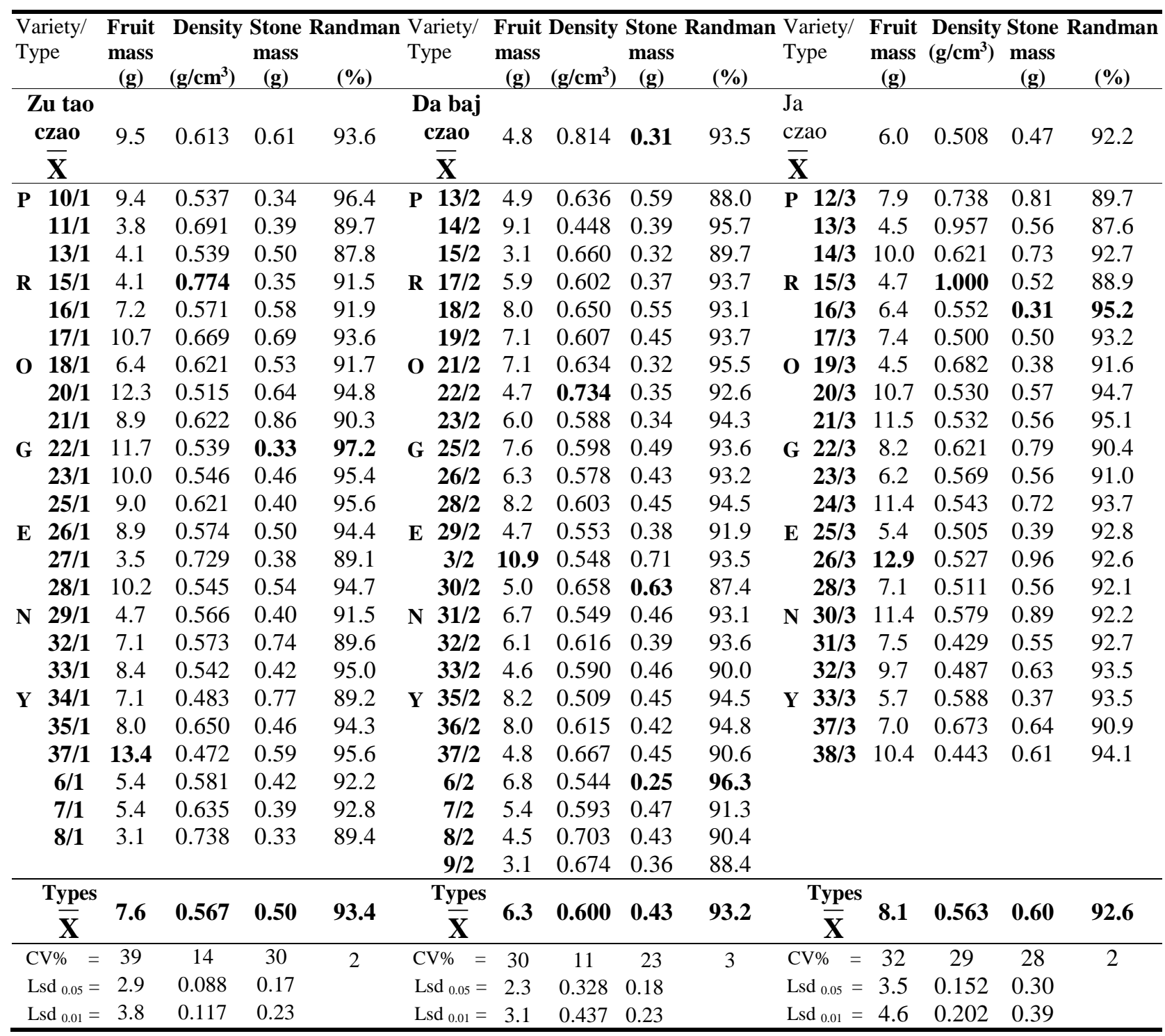


A lot of variations existed in ber genotypes for pulp/stone ratio. The pulp/stone ratio was maximum in Sanur-6 and minimum in Punjab Chhuhara [7]. The pulp/stone ratio was the highest in Umran [1]. The same authors reported the highest pulp/stone ratio in HB-2, a wild local strain of $Z$. jujuba.

The mother variety of Ja czao produced progeny that on average insignificantly exceeded the mother statistically in terms of the fruit mass $(8.1 \mathrm{~g})$ (Table 1). Actually, as a medium large fruit variety, Ja czao gave progeny with big fruits, similar to the types in the progenies of the varieties Kitajski $2 \mathrm{~A}(8.9 \mathrm{~g})$ and Vahshski 45/2 (8.1 g) which had the largest fruits. As well as in the other investigated progenies, the coefficient of variation in this progeny was the highest regarding the mass of the fruits (32\%).

The type 26/3 was characterized with the largest mass of the fruits $(12.9 \mathrm{~g})$, which statistically very significantly deviates in relation to the fruit mass of the mother variety Ja czao fruits. The type $26 / 3$ statistically showed very significantly larger mass of the fruits than $62 \%$ of the types in progeny. The type 16/3 was characterized with the smallest seeds $(0.31 \mathrm{~g})$, and with the highest randman of the fruits $(95.2 \%)$ from progeny (Table $1)$. In the progeny of the variety Ja czao the types $15 / 3\left(1.000 \mathrm{~g} / \mathrm{cm}^{3}\right)$ and $13 / 3\left(0.957 \mathrm{~g} / \mathrm{cm}^{3}\right)$ were recorded, with significantly bigger fruit density compared to types from all investigated progenies.

In the progeny of the mother form Wild Midleasiatic jujube, which statistically had the significantly biggest fruits, compared to the mother $(5.2 \mathrm{~g})$ and the average of the progeny $(7.4 \mathrm{~g})$, the type 35/4 (13.3 g) was characterized. The type 14/4 had statistically very significantly larger fruit density $\left(0.909 \mathrm{~g} / \mathrm{cm}^{3}\right)$ than the average of the progeny $\left(0.548 \mathrm{~g} / \mathrm{cm}^{3}\right)$ (Table 2$)$.

Table 2. Fruit characteristics of the varieties Wild M. jujube, Vahshski 45/2, Kitajski 2A and their progenies

\begin{tabular}{|c|c|c|c|c|c|c|c|c|c|c|c|c|c|c|}
\hline $\begin{array}{l}\text { Variety/ } \\
\text { Type }\end{array}$ & $\begin{array}{c}\text { Fruit } \\
\text { mass } \\
(\mathrm{g})\end{array}$ & $\begin{array}{l}\text { Density } \\
\left(\mathrm{g} / \mathrm{cm}^{3}\right)\end{array}$ & $\begin{array}{l}\text { Stone } \\
\text { mass } \\
(\mathrm{g})\end{array}$ & $\begin{array}{c}\text { Randman } \\
(\%)\end{array}$ & $\begin{array}{l}\text { Variety/ } \\
\text { Type }\end{array}$ & $\begin{array}{c}\text { Fruit } \\
\text { mass } \\
(\mathrm{g})\end{array}$ & $\begin{array}{l}\text { Density } \\
\left(\mathrm{g} / \mathrm{cm}^{3}\right)\end{array}$ & $\begin{array}{c}\text { Stone } \\
\text { mass } \\
(\mathrm{g})\end{array}$ & $\begin{array}{c}\text { Randman } \\
(\%)\end{array}$ & $\begin{array}{l}\text { Variety/ } \\
\text { Type }\end{array}$ & $\begin{array}{c}\text { Fruit } \\
\text { mass } \\
(\mathrm{g})\end{array}$ & $\begin{array}{l}\text { Density } \\
\left(\mathrm{g} / \mathrm{cm}^{3}\right)\end{array}$ & $\begin{array}{c}\text { Stone } \\
\text { mass } \\
(\mathrm{g})\end{array}$ & $\begin{array}{c}\text { Randman } \\
(\%)\end{array}$ \\
\hline \multirow{2}{*}{$\begin{array}{l}\text { Wild M. } \\
\text { jujube }\end{array}$} & \multicolumn{9}{|c|}{ Vahshski } & \multicolumn{5}{|c|}{ Kitajski } \\
\hline & 5.2 & 0.813 & 0.32 & 93.8 & $\frac{45 / 2}{(\bar{X})}$ & 11.7 & 0.534 & 0.56 & 95.2 & $\frac{2 \mathrm{~A}}{(\overline{\mathrm{X}})}$ & 13.1 & 0.652 & 1.01 & 92.3 \\
\hline P 10/4 & 4.6 & 0.821 & 0.45 & 90.2 & $P \quad 11 / 5$ & 7.1 & 0.555 & 0.57 & 92.0 & P $13 / 6$ & 3.4 & 0.618 & 0.33 & 90.3 \\
\hline $13 / 4$ & 5.5 & 0.611 & 0.39 & 92.9 & $15 / 5$ & 5.9 & 0.678 & 0.44 & 92.5 & $14 / 6$ & 7.1 & 0.534 & 0.54 & 92.4 \\
\hline $14 / 4$ & 5.0 & 0.909 & 0.28 & 94.4 & $16 / 5$ & 4.9 & 0.671 & 0.47 & 90.4 & $21 / 6$ & 22.2 & 0.496 & 0.62 & 97.2 \\
\hline $16 / 4$ & 1.8 & 0.692 & 0.18 & 90.0 & R $17 / 5$ & 12.7 & 0.474 & 0.62 & 95.1 & R $22 / 6$ & 16.0 & 0.500 & 0.84 & 94.8 \\
\hline $17 / 4$ & 9.4 & 0.635 & 0.59 & 93.7 & $18 / 5$ & 8.0 & 0.615 & 0.54 & 93.3 & $24 / 6$ & 10.5 & 0.430 & 0.62 & 94.1 \\
\hline $18 / 4$ & 5.6 & 0.571 & 0.42 & 92.5 & $19 / 5$ & 7.7 & 0.527 & 0.40 & 94.8 & $31 / 6$ & 5.8 & 0.537 & 0.47 & 91.9 \\
\hline $19 / 4$ & 6.0 & 0.561 & 0.56 & 90.7 & O $23 / 5$ & 8.0 & 0.630 & 0.42 & 94.8 & о $33 / 6$ & 4.6 & 0.697 & 0.37 & 92.0 \\
\hline $21 / 4$ & 11.1 & 0.603 & 0.56 & 95.0 & $24 / 5$ & 8.8 & 0.583 & 0.65 & 92.6 & $37 / 6$ & 3.9 & 0.780 & 0.51 & 86.9 \\
\hline $22 / 4$ & 6.5 & 0.556 & 0.63 & 90.3 & $25 / 5$ & 15.7 & 0.506 & 0.55 & 96.5 & $40 / 6$ & 8.6 & 0.562 & 0.49 & 94.3 \\
\hline G $23 / 4$ & 8.0 & 0.556 & 0.54 & 93.3 & G $26 / 5$ & 9.4 & 0.452 & 0.93 & 90.1 & G 41/6 & 10.3 & 0.493 & 0.57 & 94.5 \\
\hline $24 / 4$ & 8.3 & 0.447 & 0.43 & 94.8 & $27 / 5$ & 4.5 & 0.600 & 0.37 & 91.8 & $9 / 6$ & 5.8 & 0.592 & 0.53 & 90.9 \\
\hline $25 / 4$ & 6.0 & 0.667 & 0.45 & 92.5 & $31 / 5$ & 6.2 & 0.466 & 0.42 & 93.2 & & & & & \\
\hline $26 / 4$ & 7.7 & 0.503 & 0.63 & 91.8 & $32 / 5$ & 10.2 & 0.505 & 0.37 & 96.4 & $\mathbf{E}$ & & & & \\
\hline $27 / 4$ & 9.6 & 0.397 & 0.60 & 93.8 & $33 / 5$ & 4.7 & 0.734 & 0.49 & 89.6 & & & & & \\
\hline $28 / 4$ & 7.9 & 0.485 & 0.79 & 90.0 & $35 / 5$ & 8.2 & 0.577 & 0.57 & 93.0 & & & & & \\
\hline $29 / 4$ & 11.8 & 0.509 & 0.62 & 94.7 & $38 / 5$ & 6.1 & 0.610 & 0.34 & 94.4 & $\mathbf{N}$ & & & & \\
\hline $30 / 4$ & 4.6 & 0.505 & 0.51 & 88.9 & $6 / 5$ & 9.2 & 0.495 & 0.54 & 94.1 & & & & & \\
\hline $31 / 4$ & 6.0 & 0.492 & 0.33 & 94.5 & $7 / 5$ & 9.3 & 0.472 & 0.62 & 93.3 & & & & & \\
\hline Y $\quad 32 / 4$ & 5.9 & 0.457 & 0.43 & 92.7 & $\mathbf{Y}$ & & & & & $\mathbf{Y}$ & & & & \\
\hline $34 / 4$ & 8.8 & 0.444 & 0.32 & 96.4 & & & & & & & & & & \\
\hline $35 / 4$ & 13.3 & 0.591 & 0.70 & 94.7 & & & & & & & & & & \\
\hline $37 / 4$ & 9.1 & 0.448 & 0.41 & 95.5 & & & & & & & & & & \\
\hline$\frac{\text { Types }}{\mathbf{X}}$ & 7.4 & 0.548 & 0.49 & 93.4 & $\frac{\text { Types }}{\mathbf{X}}$ & 8.1 & 0.523 & 0.51 & 93.7 & $\frac{\text { Types }}{\mathbf{X}}$ & 8.9 & 0.511 & 0.54 & 93.9 \\
\hline $\mathrm{CV} \%=$ & 36 & 25 & 30 & 2 & $\mathrm{CV} \%=$ & 35 & 17 & 27 & 2 & $\mathrm{CV} \%=$ & 64 & 15 & 25 & 3 \\
\hline $\operatorname{Lsd}_{0.05}=$ & 2.3 & 0.203 & 0.20 & & $\operatorname{Lsd}_{0.05}=$ & 3.8 & 0.159 & 0.27 & & $\operatorname{Lsd}_{0.05}=$ & 2.9 & 0.076 & 0.15 & \\
\hline $\operatorname{Lsd}_{0.01}=$ & 3.0 & 0.270 & 0.26 & & $\operatorname{Lsd}_{0.01}=$ & 5.1 & 0.212 & 0.36 & & $\operatorname{Lsd}_{0.01}=$ & 3.9 & 0.101 & 0.19 & \\
\hline
\end{tabular}


In fact, Wild Midleasiatic jujube was characterized with a larger variation of fruit density in the progeny (Table 2), compared with other progenies. Significant genotypic differences were found in the seed characters of $Z$. jujuba varieties [1]. Saran [5] observed variations in the stone size of 35 cultivars of ber and reported that maximum $(3.72 \mathrm{~cm})$ was in Ponda and the minimum $(0.53$ $\mathrm{cm})$ in Illaichi. The type $16 / 4$ had statistically very significantly smaller seed than $59 \%$ of the types in the progeny $(0.18 \mathrm{~g})$, showing also significant differences from the average of the types $(0.49 \mathrm{~g})$ in the progeny (Table 2 ).

The mother variety Vahshski $45 / 2$ belonged to the group of jujube varieties with large fruits. Its progeny was characterized with large fruits $(8.1 \mathrm{~g})$ on average, but statistically insignificantly smaller fruits than the mother variety Vahshki 45/2 (11.7 g). According to the dimensions of the fruits in the progeny, the Vahshki 45/2 was just behind the variety Kitajski $2 \mathrm{~A}$. The type $25 / 5$ from its progeny was characterized with the largest fruits.

The fruits of this type were statistically very significantly larger ( $15.7 \mathrm{~g}$ ) compared with the average of the progeny $(8.1 \mathrm{~g})$ and also with the fruits of the mother variety $(11.7 \mathrm{~g})$ (Table 2$)$. It can be noted, that the average of the types from this progeny, estimated for all investigated characteristics except fruit mass, was most uniform with the mother variety, unlike other mother varieties (Table 2).

The best Zizyphus jujuba varieties for uniformity of fruit size were Ta-Pai and Hsueh-pai [2]. The type 38/5 was characterized with smaller seeds without statistically significant difference in terms to the mother variety and the average of the progeny. The seeds of Zizyphus mauritiana trees taken from five districts in Yunnan Province, China and Narkum, Myanmar, were tested for their morphological characteristics, germination characteristics, and the growth patterns of the seedlings and young trees. A close relationship was found between these characters and their geographical distribution and climatic conditions [8].

The progeny of the Kitajski 2A mother variety (although few in number) was characterized with exceptional examples. About $36 \%$ of the types from its progeny had larger fruit mass than $10 \mathrm{~g}$. The type 21/6 was characterized with the largest fruit mass $(22.2 \mathrm{~g})$. Its fruits in average were statistically very significantly larger not only from those ones of its mother (Kitajski 2A) which had the largest ones between investigated varieties, but also from all types which were obtained from the progenies. The goal of the investigation was actually accomplished with this type, producing types that would be better than their mother varieties. In this progeny another type 22/6 was obtained with statistically significantly larger fruits $(16 \mathrm{~g})$, than the mother variety and in relation to the other mother varieties and types in the progenies.

Pewandi was considered to be the best variety for commercial cultivation, having the largest fruit, a high percentage of edible pulp and good skin colour [1]. There were considerable differences among seven ber cultivars in fruit weight (29.340 to $9.544 \mathrm{~g}$ ), fruit size (length 3.27-4.33 cm), pulp/seed ratio and fruit quality in Ratta Kulachi, D. I. Khan, Pakistan [1]. Even in an early stadium of hybrid seedling development (in the first or second year) the genotypes with large fruits size could be registered, especially in the third fruit growth period, and that was very useful for an early positive selection of the Chinese jujube perspective types [9].

The type $21 / 6$ was characterized with the highest randman $(97.2 \%)$ among the varieties and types (Table 2). The mother variety Kitajski $2 \mathrm{~A}$ had seeds with statistically very significantly higher mass $(1.01 \mathrm{~g})$ compared with other varieties and types in the progenies. The type 37/6 was characterized with statistically very significantly larger fruit density $\left(0.780 \mathrm{~g} / \mathrm{cm}^{3}\right)$ than its mother $(0.652$ $\mathrm{g} / \mathrm{cm}^{3}$ ) and compared with the average of the progeny $\left(0.511 \mathrm{~g} / \mathrm{cm}^{3}\right)$. A very significant difference was recorded in the mass of the seeds of the type 13/6 which had the smallest seeds (0.33 g), compared with the mother variety $(1.01 \mathrm{~g})$ and the average of the progeny $(0.54 \mathrm{~g})$ (Table 2$)$.

The determination of the genetic parameters clarifies the investigated characteristic variation in progenies (Table 3). The genotypic coefficient of variation $(\mathrm{GCV})$ is the highest for fruit and seed mass compared with the other investigated characteristics (fruit density and randman), but the phenotypic coefficient of variation (PCV) for these characteristics was also higher, which indicates the stronger influence of the environmental factors, especially this refers to the characteristics of fruit mass. The range of genetic variability of the seed mass in each of the progenies was higher than GCV of all progenies which indicates a stronger mother influence on inheritance. The progenies of the mother varieties Vahshski 45/2 and Ja czao had the highest GCV for fruit and seed mass than the other varieties (Table 3). The jujube progenies had the lowest GCV for the randman characteristics of the fruit, with an exception to the progeny of the variety Da bai czao. The estimates showed moderate heritability $\left(\mathrm{H}^{2}\right)$ for all investigated characteristics. The high heritability, coupled with high genetic 
advance (GA), was noted for progenies' fruit mass. It especially relates to fruit mass of the Kitajski $2 \mathrm{~A}$ progeny $\left(\mathrm{H}^{2} 64.5 \%\right.$ and GA $\left.39.7 \%\right)$, which means that in this variety it is much easier to obtain inheritance with high fruit mass genotypes through further individual selection. The higher are the values of GCV, heritability and genetic advance (GA) for some characteristics, the same characteristics can be more improved through the selection process [10]. However, moderate to low heritability and genetic advance suggested a polygenic influence and quite weak additional gene effect (Kitajski 2A) on the creation of the Chinese jujube fruit characteristics (Table 3).

Table 3. Genetic parameters for some fruit characteristics of the jujube genotypes

\begin{tabular}{|c|c|c|c|c|c|}
\hline \multirow[b]{2}{*}{ Variety progenies } & \multirow[b]{2}{*}{$\begin{array}{l}\text { Characteristics range } \\
\qquad(\min -\max )\end{array}$} & \multicolumn{4}{|c|}{ Genetic parameters } \\
\hline & & $\begin{array}{c}* \text { GCV } \\
(\%)\end{array}$ & $\begin{array}{c}* P C V \\
(\%)\end{array}$ & $\begin{array}{l}* \mathbf{H}^{2} \\
(\%)\end{array}$ & $\begin{array}{c}* \text { GA } \\
(\% \text { of mean })\end{array}$ \\
\hline \multicolumn{6}{|c|}{ Fruit mass (g) } \\
\hline Zu tao czao & $2.5-17.2$ & 19.0 & 38.4 & 54.0 & 20.1 \\
\hline Da bai czao & $2.1-13.0$ & 18.3 & 34.2 & 49.6 & 16.9 \\
\hline Ja czao & $3.5-15.4$ & 21.0 & 37.0 & 41.8 & 15.0 \\
\hline Wild jujube & $0.9-15.2$ & 15.4 & 35.0 & 57.9 & 19.7 \\
\hline Vahsh.45/2 & $4.2-17.1$ & 23.5 & 44.1 & 44.3 & 19.0 \\
\hline Kitajski 2A & $2.9-24.0$ & 16.2 & 63.7 & 64.5 & 39.7 \\
\hline All progenies & $0.9-24.0$ & 16.6 & 24.6 & 57.3 & 15.0 \\
\hline \multicolumn{6}{|c|}{ Fruit density $\left(\mathrm{g} / \mathrm{cm}^{3}\right)$} \\
\hline Zu tao czao & $0.45-0.97$ & 7.3 & 14.1 & 51.1 & 7.0 \\
\hline Da bai czao & $0.39-0.98$ & 13.2 & 22.1 & 40.0 & 8.7 \\
\hline Ja czao & $0.42-1.27$ & 11.7 & 27.4 & 58.5 & 15.6 \\
\hline Wild jujube & $0.34-1.34$ & 17.2 & 30.9 & 44.7 & 13.4 \\
\hline Vahsh.45/2 & $0.42-0.92$ & 13.5 & 24.6 & 41.2 & 9.8 \\
\hline Kitajski 2A & $0.44-0.84$ & 6.6 & 17.9 & 56.9 & 9.9 \\
\hline All progenies & $0.34-1.34$ & 12.7 & 17.4 & 48.0 & 7.7 \\
\hline \multicolumn{6}{|c|}{ Seed mass $(\mathrm{g})$} \\
\hline Zu tao czao & $0.17-1.05$ & 17.4 & 32.5 & 48.8 & 15.4 \\
\hline Da bai czao & $0.18-0.76$ & 19.4 & 31.4 & 35.4 & 11.0 \\
\hline Ja czao & $0.17-1.20$ & 24.3 & 38.0 & 26.4 & 9.7 \\
\hline Wild jujube & $0.14-0.87$ & 20.2 & 36.1 & 43.9 & 15.4 \\
\hline Vahsh.45/2 & $0.25-1.17$ & 26.7 & 42.6 & 24.7 & 10.2 \\
\hline Kitajski 2A & $0.3-0.95$ & 13.6 & 32.3 & 51.3 & 16.1 \\
\hline All progenies & $0.14-1.20$ & 4.3 & 14.5 & 62.8 & 9.2 \\
\hline \multicolumn{6}{|c|}{ Randman (\%) } \\
\hline Zu tao czao & 84.5-97.3 & 1.4 & 2.3 & 55.0 & 1.5 \\
\hline Da bai czao & $83.3-97.2$ & 9.2 & 18.0 & 52.7 & 9.2 \\
\hline Ja czao & $84.5-97.4$ & 1.8 & 2.9 & 33.2 & 0.9 \\
\hline Wild jujube & $82.2-97.4$ & 1.7 & 3.0 & 42.4 & 1.2 \\
\hline Vahsh.45/2 & $88.7-97.1$ & 1.1 & 2.3 & 52.7 & 1.2 \\
\hline Kitajski 2A & $81.4-98.0$ & 1.6 & 3.9 & 53.6 & 2.0 \\
\hline All progenies & $81.4-98.0$ & 1.6 & 2.2 & 46.6 & 1.0 \\
\hline
\end{tabular}

*GCV - Genotypic coefficient of variation, PCV - Phenotypic coefficient of variation, $\mathrm{H}^{2}$ - Heritability, GA - Genetic advance

\section{CONCLUSIONS}

The investigated characteristics: fruit density and mass of the seed in the progenies of jujube varieties showed that they were low dependent from the mass of the fruit. Namely, the jujube types with small fruits statistically had insignificantly higher fruit density, but also the higher coefficient of variation of fruit density in relation to the types with large fruits. Also, the jujube types with large fruits had again statistically insignificantly higher mass of the seed, with high coefficient of variation in relation to the types with small fruits. The sublimated investigations showed that the mother varieties with 
medium to large fruits (Kitajski 2A, Vahshski 45/2, and $\mathrm{Zu}$ tao czao) had on average bigger mass of the fruit, mass of the seed and fruit density than the average of the types in their progenies, while the varieties with small fruits (Ja czao, Da baj czao, Wild Middleasiatic jujube) had only bigger fruit density than the average of the types in their own progeny. The investigations showed that within the frames of jujube species it was very difficult to obtain types with very large fruits, but genetic parameters indicated that there were more chances to get such examples from the seeds of varieties and types with large fruits, so I recommend to use open pollination or hybridization between varieties or types with large fruits for obtaining types with larger fruits in the future breeding programs.

\section{REFERENCES}

[1] S. Azam-Ali, E. Bonkoungou, C. Bowe, C. deKock, A. Godara, J. T. Williams, Ber and other jujubes, Monograph, International Centre for Underutilised Crops, Southampton, UK, 2006.

[2] O. Grygorieva, V. Abrahamová, M. Karnatovská, R. Bleha, J. Brindza, Morphological characteristics of fruits, drupes and seeds in genotypes of Zizyphus jujuba Mill. Potravinarstvo, 8, 1 (2014), pp. 306-314.

[3] W. Hoffmann, A. Mudra, W. Plarre, Lehrbuch der Züchtung landwirtschaftlicher Kulturpflanzen, Band 2, spezieller Teil, 2. Auflage, Verlag Paul Parey, Berlin und Hamburg, 1985.
[4] A. Markovski, L. Velkoska-Markovska, Investigation of the morphometric characteristics of jujube types (Zizyphus jujuba Mill.) fruits in Republic of Macedonia, Genetika, 47, 1 (2015), pp. 33-43.

[5] P. L. Saran, Studies on genetic divergence in ber (Zizyphus mauritiana Lamk.) germplasm, Ph.D. thesis, CCS Haryana Agricultural University, Hisar, India, 2005.

[6] K. H. Arunkumar, M. G. Patil, C. N. Hanchinamani, I. Shanker Goud, S. V. Hiremath, Genetic relationship of growth and development traits with fruit yield in $\mathrm{F}_{2}$ population of BGDL $\times$ Hotseason of cucumber (Cucumis sativus L.), Karnataka J. Agric. Sci., 24, 4 (2011), pp. 497-500.

[7] S. G. Bharad, D. V. Mali, V. G. Ingle, M. A. Sagane, Effect of time and severity of pruning on physico-chemical characteristics and yield in ber varieties, PKV-Research Journal, 26, 1/2 (2002), pp. 31-35.

[8] Wang-Yun, Y. Wang, A preliminary study on the geographical provenance of Zizyphus mauritiana, Forest Research, 7, 3 (1994), pp. 334-335.

[9] A. Markovski, L. Velkoska-Markovska, Dynamics of jujube (Zizyphus jujuba Mill.) fruit growth, Challenges in Modern Agricultural Production, Skopje, Macedonia, 2015, Book of Proceedings, Institute of Agriculture, pp. 63-69.

[10] M. N. Islam, M. M. Hossain, M. M. Rahman, M. S. Uddin, M. M. Rohman, Heritability, correlation and path coefficient analysis in twenty ber genotypes, Academic Journal of Plant Sciences, 3, 2 (2010), pp. 92-98.

\title{
КАРАКТЕРИСТИКИ НА ПЛОДОВИТЕ НА РАЗЛИЧНИ ПОТОМСТВА ОД КИНЕСКА УРМА (ZIZYPHUS JUJUВA MILL.)
}

\author{
Александар Марковски \\ Земјоделски институт, Универзитет „Св. Кирил и Методиј“, Скопје, Република Македонија
}

Во периодот 2002-2004 во опитните насади на Земјодлескиот институт во Скопје се испитувани помолошките карактеристики на пет сорти и еден див тип на кинеска урма. Семето од сортите: Жу тао цзао, Да бај цзао, Китајски 2А, Ја цзао, Вахшски 45-2 и од типот Дива средноазиска е добиено по пат на слободно опрашување. Кај 7-9 годишните самоници кинеска урма добиени од тоа семе, кои се посадени во селекционо поле, се испитувани некои карактеристики на плодовите: маса на плодовите $(\mathrm{g})$, густина на плодовите $\left(\mathrm{g} / \mathrm{cm}^{3}\right)$, маса на семето $(\mathrm{g})$ и рандманот $(\%)$. Доминантен мајчин ефект во наследувањето е забележан кај масата и густината на плодовите. На пример: со најголема маса на плодовите се карактеризира сортата Китајски 2А и типовите од нејзиното потомство, додека со најголема густина на плодовите се карактеризира мајчинската сорта Да бај цзао и типовите од нејзиното потомство. Најголема маса на семето е забележана кај сортата Китајски $2 \mathrm{~A}$, додека со просечно најголема маса на семето се карактеризира потомството од сортата Ја цзао.

Клучни зборови: Кинеска урма; слободно опрашување; сорта; тип; плод 
